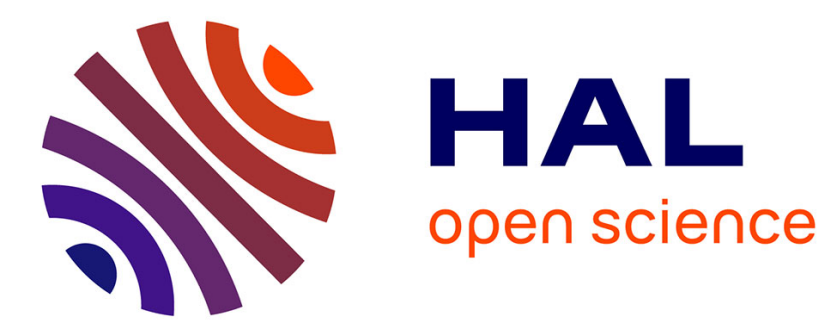

\title{
The Relative Age Effect in Elite Sport: The French Case
}

Nicolas Delorme, Julie Boiché, Michel Raspaud

\section{To cite this version:}

Nicolas Delorme, Julie Boiché, Michel Raspaud. The Relative Age Effect in Elite Sport: The French Case. Research Quarterly for Exercise and Sport, 2009, 80 (2), pp.336-344. 10.5641/027013609x13087704028796 . hal-00347631

\section{HAL Id: hal-00347631 \\ https://hal.science/hal-00347631}

Submitted on 13 Aug 2009

HAL is a multi-disciplinary open access archive for the deposit and dissemination of scientific research documents, whether they are published or not. The documents may come from teaching and research institutions in France or abroad, or from public or private research centers.
L'archive ouverte pluridisciplinaire HAL, est destinée au dépôt et à la diffusion de documents scientifiques de niveau recherche, publiés ou non, émanant des établissements d'enseignement et de recherche français ou étrangers, des laboratoires publics ou privés. 
2 The relative age effect (RAE) is considered as a common phenomenon in elite sport.

3 However, it was not observed systematically in previous research and the mechanisms likely

4 to generate or to limit such an effect remain misunderstood. In this paper we aimed at

5 checking the prevalence of the RAE in French professional championships, taking into

6 account the potential influence of sex. Among all investigated sports, no statistically

7 significant RAE was found, except for male ice hockey. For male handball and rugby union a

8 trend was detected but the RAE did not appear statistically significant. In line with previous

9 studies, no significant RAEs were found in female elite sports. The results are discussed with

10 regard to the potential mechanisms underlying $\mathrm{RAE}$.

12 Keywords: Birth date, sex differences, French professional championships. 


\section{The Relative Age Effect in Elite Sport: The French Case} (1)

Recently, a growing body of research has considered the relationship between athletes' month of birth and their achievement at the highest level of practice. These studies are based on the concept of 'relative age'. This term refers to the difference in age between children in the same age group (Musch \& Grondin, 2001). Thus, although a child born in January is 11 months older than a child born in December of the same year, both children are grouped in the same age category in an age-based system with January 1 st as cut-off date. The potential consequences of relative age are labelled under the term 'relative age effect' (RAE). As pointed by Musch and Grondin (2001), the RAE is a far less well-recognised phenomenon in sport, compared to the educational context, and no effective strategies have been implemented to counter the negative consequences of a low relative age. The RAE has been viewed as discriminating against players born late in the competition years (e.g., Edgar \& O'Donoghue, 2005; Simmons \& Paull, 2001). While this kind of discrimination may be unintentional, it should be a cause for concern given the lucrative nature of professional sport.

6 Most of the publications consider the cut-off dates used to determine youth categories as the only, or at least the major cause, for the RAE. Musch and Grondin (2001) questioned the possibility of several causal factors of the relative age effect (i.e., climatical, environmental, sociocultural and biological influences) but concluded that only the cut-off date can explain the existence of the $\mathrm{RAE}^{1}$. Basically, differences between children who belong to the same age category but who differ in age up to almost one year could result either in a volunteer dropout of the youngest players, or in an official selection of the oldest players to participate to high level trainings or to belong to national youth teams. Those two phenomena (i.e., dropout and recruitment) are likely to facilitate an elite career for oldest players, that are born after the cut-off date. Among elite adults, this process is reflected by a 
1 similar imbalance in players' birthdates distribution, with an over-representation of players

2 born in the months after the cut-off date, and an under-representation of players born in the

3 months before.

In their review of the literature on RAE in sport, Musch and Grondin (2001) conclude to a pervasive, yet not universal, phenomenon. Indeed, even if a major part of the studies revealed a significant RAE in elite populations, this significant result was not observed systematically for all sport, all periods, and both sexes. These authors underlined the fact that multiple factors may account for the presence or absence of this phenomenon. In the next section, we briefly present the main elements that they emphasise as potential determinants of the RAE.

\section{Determinants of the RAE}

Competition. The first factor likely to enhance a RAE in sport, according to Musch and Grondin (2001) is competition. Indeed, if competition is low, every player can belong to a team and participate to team events, because there is a place for everyone. As the authors state, "the larger the pool of potential players, for a given sport in a given category, the strongest the resulting RAE should be" (Musch \& Grondin, 2001, p. 154). This assumption is largely supported by previous research.

First, RAEs were observed more often in popular sports, compared to activities that concern fewer participants in a given country. For example, ice hockey can be considered as the most popular sport in Canada, and a significant RAE was observed in a major part of the 21 samples studied (e.g., Grondin, Deshaies \& Nault, 1984; Grondin \& Trudeau, 1991; Krouse, 22 1995) with percentage of players born in the first half of the year superior to $70 \%$ (e.g., Barnsley \& Thompson, 1988; Barnsley, Thompson \& Barnsley, 1985). On the other hand, volleyball, a far less popular activity in this country, shows weak or only moderate RAEs (Grondin et al., 1984; Ryan, 1989). In the same vein, the studies conducted on soccer in 
1 countries were this sport is very popular reveal important RAEs (e.g., in the UK: Brewer,

2 Balsom \& Davis, 1995; in Belgium: Helsen, Starkes \& van Winckel, 1998; in Belgium,

3 France and Netherlands: Verhulst, 1992).

Second, several studies indicated differences in RAE according to the level of practice: the highest the level of practise, the biggest RAE was. This pattern was more

6 particularly observed for ice hockey and volleyball (Grondin et al., 1984). Finally, a study by

7 Daniel and Janssen (1987) indicate that there was no RAE in elite ice hockey in the seasons 61-62 or between 1972 and 1975, but that it appears significant for the season 85-86.

9 Subsequent research shows a similar pattern for professional players (e.g., Grondin \& Trudeau, 1991; Krouse, 1995). This evolution is coherent with the development of leisure sport and the consequent increase in the number of young people likely to participate to this activity (Daniel \& Janssen, 1987). to explain the RAE phenomenon is physical development. In a competitive context, youngest players that are less mature physically could be disadvantaged compared to their older counterparts. Indeed, they are likely to demonstrate lower stature and weight, which are considered as significant determinants of success in certain sport such as ice hockey (e.g., Barnsley \& Thompson, 1988). This assumption received a certain support in previous studies. For example, Grondin and Trudeau (1991) observed that the extent of the RAE in ice hockey depended on the position occupied, and that it was maximal among goalkeepers, the position recognized as the most physically demanding because of the heavy material. In the same vein, an early maturation could be a facilitating characteristic because it would increase the chances of selection in youth age categories. Several studies did report an advanced physical maturity among young elite athletes (e.g., Brewer et al., 1992; Garganta, Maia, Silva \& Natal, 1993). 
Conversely, in certain sports, such as gymnastics or dance, it is not an early, but a late

2 maturation, that is considered as advantaging (Malina, Bouchard \& Bar-Or, 2004). Late maturation has indeed been observed among elite gymnasts (e.g., Malina, 1994), and BaxterJones (1995) observed no RAE among British elite gymnasts. The same seems true for dancers, as Van Rossum (2006) reported no RAE among samples of young dancers belonging to pre-professional schools.

In his article, Van Rossum (2006) defends the idea that physical capacities may be a determinant factor of success in certain activities, but that in other sports, other elements, such as technical or motor skills, are more important. Regarding team sports, the degree of contact allowed between players can be considered as a relevant characteristic, and physical attributes are undoubtedly a more critical issue in contact sports like soccer or ice hockey, than in noncontact sports volleyball or basketball. In this vein, looking at the American male professional championship, Daniel and Jansen (1987) or Côté, McDonalds, Baker and Abernethy (2006) did not find any significant RAE. This absence of RAE may be explained by the fact that basketball is a sport with specific positions, such as guard, which allow players with less physical attributes to express themselves through other abilities (e.g., assists, steals). This said, one should consider the prevalence of physical attributes for success in one given sport, and the sense of this eventual advantage (i.e., facilitating versus inhibiting role of an early maturation) prior to formulate hypotheses relative to the potential RAE to be observed ${ }^{2}$. The Question of Sex. As pointed by Musch and Grondin (2001) little is known about

21 the role of sex in the RAE. In fact, the vast majority of this literature concerned male athletes.

22 To our knowledge, only three studies also reported data for female athletes (Baxter-Jones, 1995; Van Rossum, 2006; Vincent \& Glamser, 2006). Baxter-Jones (1995) investigated elite British gymnasts and observed no significant RAE among males or females. The same pattern of results was reported by Van Rossum (2006) among elite Dutch dancers. The paper of 
1 Vincent and Glamser (2006) concerned 1344 players considered by the US Olympic

2 Development Program in 2001 to be the most talented soccer players born in 1984 . The

3 results revealed only a marginal RAE for females belonging to regional and national teams,

4 and no RAE for state team players, whereas a strong RAE was found among males belonging

5 to all teams, whatever the level considered. These mixed results can be summarized as

6 following: in activities where RAE appears, it is less important among females.

A first explanation of this difference could be a less important competition among female to gain their position in an elite team. If an activity is far more popular among boys than girls in a given country, and if similar elite structures exist with a similar selection system, it is not surprising to find higher RAEs among males than among females. The second major determinant, physical development, also deserves to be interrogated with regard to potential sex differences. Baxter-Jones (1995) suggested that the stronger RAE among male athletes is the result of the earlier maturation of girls and the higher variance of the maturity status of boys. During the period of selection, there would thus be more important differences between boys than between girls. Vincent and Glamser (2006, p. 412) argued that social pressures to conform to a socially constructed gender role (i.e. stereotyped definition of femininity) 'could make early maturing females less motivated to achieve excellence in competitive sport because of a perception that society does not value female athletic accomplishments in the same way it does those of males'. Shakib (2003) provided a good illustration of this phenomenon in her study about female basketball participation, showing that before and after puberty, girls' peer statuses and gender statuses are conflated. Girls have to renegotiate a tension between popularity (i.e., peer status) and athleticism. Thus, early maturing females are more subject to leave competitive sports than later maturing females. The physical advantage provided by an early maturation to excel more early in certain sports would thus be more profitable among boys than among girls. 


\section{Characteristics of the French sport system}

In addition to universal factors that may lead to a RAE in any place for a given sport, certain cultural contexts may enhance or limit this phenomenon. As much of past research was done in North-America, or European countries other than France, we develop briefly some specificities of the French sport system that may explain the results of the present study. The first factor that shapes the French sport system is the important participation and regulation by the government, which has strongly influenced the historical expansion of elite sport. Among all European countries, France is the one where the government is the most interventionist in sport (Bourdieu, Dauncey \& Hare, 1998). Because of this interventionism, elite sport had difficulties to accept and to adapt to new constraints of commercialisation: the concept of "French exception" had been threatened, notably by the globalisation of soccer and the recent authority of elite clubs on French soccer federation (Dauncey \& Hare, 1999). The French government justifies its interventionism by the need to make sure that the general interest given to sport will be more important than the multitude of personal interests which go through it (Holt, 1981). For Dauncey and Hare (1999), France remains true to its strongest belief: sport must be a public utility. For example, the soccer world champion title won by France in 1998 had been used as a means of promoting social inclusion and national solidarity (Dine, 2003). Given the hegemonic development of professional sport, such a position seems paradoxical. In order to obtain subventions from the French government, sport federations have to be recognised by a Ministry which takes charge of sport. This Ministry delegates the organisation and the regulation of certain activities to the federations. There is a real supervision from the government: it has the ability to ratify the decisions of the sports federations, given that it has only delegated it's authority to the federation in the name of French citizens. Consequently, the French government keeps the situation in hand concerning sport's organisation. 
The second French specificity is the main organisation of sport in structures (e.g.,

2 clubs, federations) labelled "Loi 1901" [law 1901]. That way, the whole amateur sphere is

3 functioning respecting the principle that elected administrators cannot take personal

4 advantages of their position (e.g., earning money, having benefits in kind). The

5 professionalization of high-level sport thus has forced elite clubs to adopt different juridical

6 structures in order to adapt to the commercialisation of these activities. However, the French

7 professionalization of elite sport is atypical with regard to others European countries. For example, Gouguet and Primault (2006) recently showed that French professional soccer is not

9 in a bad situation, whereas currently, European professional soccer goes through a deep

financial crisis. For these authors, the French specific organisation of elite sport explains this

11 success. They showed that this organisation is based upon three pillars: solidarity (i.e., revenue sharing), training (by all clubs) and financial control. Those characteristics place France in a particular situation that may influence the occurrence of RAE among elite 14 athletes.

\section{Purpose of the study and hypotheses} professional championships in a variety of sports (i.e., soccer, basketball, handball, ice hockey, volleyball and rugby union) considering both male and female elite athletes. Based on (a) previous research conducted on the RAE among elite samples, (b) the prevalence of physical attributes for success, and (c) our knowledge about the situation and functioning of

21 these activities in France, we formulate the following hypotheses (see Table 1):

First, we expect a significant RAE in male soccer, handball, ice hockey and rugby union, but weak or only moderate RAE among male basketball and volleyball players. Second, we expect no - or only marginal - RAEs among all female elite samples. 
$2 * * * *$ Insert table 1 approximately here $* * * *$

Method

Data collection

For the purposes of the current investigation, birthdates of players practicing at the

6 highest level during 2005-2006 season were collected. Following Vaeyens, Philippaerts and

7 Malina (2005), the present study considered only players who were selected - at least once -

8 for a competitive match. Furthermore, players must have the French nationality to make sure

9 that they have been subject to the French recruitment system, and consequently to the same

10 cut-off dates in age categories.

Table 2 summarizes the number of players selected in each sport following those

$* * * *$ Insert table 2 approximately here $* * * *$

When collecting the data, we took care that the player was indeed a new player in the study, and not a player transferred during the season or, for female players, an existing player under a married name. 


\section{Data analysis}

In previous studies, the RAE was investigated by looking at a divergence between the expected and observed number of players born per month or per quarter (i.e., period of three consecutive months). For all of the investigated sports, the cut-off date used by national federations to construct youth categories is January 1st. Therefore, the players' dates of birth were classified into four quarters starting with January to March inclusive (Q1) and ending with October to December inclusive (Q4). Following the example of the vast majority of previous studies, expected birth date distributions were calculated for the corresponding years for the French male and female populations, using weighted means technique. Then, chisquare goodness-of-fit tests were carried out for each sport in order to determine whether or not the birthdates distribution for players was significantly different from the theoretical expected distribution. Data were provided by the National Institute of Statistics and Economics Studies. For all tests, statistical significance was set at $\mathrm{p} \leq .05$.

\section{Results}

Table 3 shows the distribution of birth dates for male and female senior players by quarters for each sport studied.

$* * * *$ Insert table 3 approximately here $* * *$

For male soccer $\left(\chi^{2}=4.76\right.$, d.f. $\left.=3, p<.190\right)$, male basketball $\left(\chi^{2}=2.89\right.$, d.f. $=3, p<$ $.408)$ and male volley ball $\left(\chi^{2}=1.96\right.$, d.f. $\left.=3, p<.581\right)$ the observed distributions are not statistically different from expected distributions. Concerning male ice hockey $\left(\chi^{2}=13.13\right.$, d.f. $=3, p<.01$ ), a strong over-representation in quarter 1 and an under-representation in quarter 4 are found. For male handball $\left(\chi^{2}=7.16\right.$, d.f. $\left.=3, p<.067\right)$ and male rugby union $\left(\chi^{2}\right.$ 
$1=7.24$, d.f. $=3, p<.065)$ a trend is detected but the RAE does not appear statistically

2 significant at $p=.05$.

3 The absence of RAE in male soccer championship $\left(\chi^{2}=4.76\right.$, d.f. $\left.=3, p<.190\right)$ is

4 quite intriguing. It should be noted that currently the more talented French soccer players

5 often leave France and move to the English, German, Italian or Spanish first division

6 championships, which are more prestigious and lucrative. Moreover, the recent study of

7 Vaeyens et al. (2005) show that players born in the first quarter have more playing

8 opportunities than others players (i.e., number of selections and playing time) and thus can be

9 considered as more capable. Given that, we might expect that French players exiled in other

10 European championships are in majority born in the first quarter. Consequently, French elite

11 championship may be less affected by RAE. In order to test this hypothesis, a new calculation

12 was done by adding to the original sample the birthdates of the 65 French soccer players from

13 the European championships cited above, based on the data of the French Football Federation.

14 The results are presented in Table 4.

**** Insert table 4 approximately here $* * * *$

17

The addition of these expatriate players do not lead to a statistically significant RAE $\left(\chi^{2}=4.65\right.$, d.f. $\left.=3, p<.199\right)$.

With regard to female players, the analyse do not reveal a RAE neither in soccer $\left(\chi^{2}=\right.$ 3.79 , d.f. $=3, p<.285)$, nor in basketball $\left(\chi^{2}=3.30\right.$, d.f. $\left.=3, p<.348\right)$, nor in handball $\left(\chi^{2}=\right.$ 0.92$, d.f. $=3, p<.820)$

Discussion

The relative inconsistency of RAE observed in previous research based on the birthdates distribution of professional athletes led us to investigate in which conditions such 
1 an asymmetry would emerge in French senior high-level championships. Different hypotheses

2 were expressed according to the nature of the activity, and more precisely the prevalence of

3 physical attributes for success (i.e., non-contact vs. high contact sports), and the competition

4 to reach the elite level (i.e., degree of popularity of the activity). Because those variables may

5 differ for males and females, we formulated specific hypotheses, in line with past research

6 conducted for both sexes.

$7 \quad$ RAE and male elite sport

As seen previously, a few sports do not seem to present significant RAE, such as basketball (Côté et al., 2006; Daniel \& Janssen, 1987), gymnastics (Baxter-Jones, 1995), American football (Daniel \& Janssen, 1987; Stanaway \& Hines, 1995) and volleyball

11 (Grondin et al. 1984). As suggested by certain authors, this absence of effect can be explained by the more important role played by technical skills in certain sports, compared to others (Van Rossum, 2006). We thus made the hypothesis that we would not find any significant RAE in basketball nor volleyball. Our findings concerning male basketball players are in line with the results of Daniel and Janssen (1987) who did not find a RAE in a sample of 297 American professional players during the 1984-85 season. More recently, Côté et al. (2006) also failed to find a RAE in the American professional basketball league during 2002-2003 season. Given the specific players positions (cf. supra), this sport seems not to be susceptible to a RAE, independently from the competition format which is different in Europe (i.e., promotion/relegation system) compared to North America. Concerning volleyball (Grondin et al. 1984), a sport without contact between players, only Canadian youth levels were investigated in past research. The authors did not find significant RAEs and explained it by the fact that there is not a strong competition to obtain a place in teams. Indeed, this variable was pointed by Musch and Grondin (2001) as a necessary 
1 licensed players in 2006). The absence of RAE in French male volleyball may be the

2 consequence of a small number of participants. The absence for other findings at the elite

3 level in the literature prevents from any comparison and speaks for the need of further

4 empirical studies.

A second category of male sports emerged. Indeed, in France, rugby union, handball and soccer all represent high contact sports with high competition for a place in an elite team.

We thus made the hypothesis that we would find a strong and significant RAE in those sports at the elite level. Rugby union and handball had not been previously investigated, so our findings cannot be set in prospect. Nevertheless, although our results did not indicate a statistically significant RAE, it should be noted that trends are present in both sports. Thus, as high contact sports where physical attributes are determinant for success, in a context of high concurrency, male rugby union and male handball seem to be likely to show this effect. However, the case of French male elite soccer remains intriguing. Compared to previous studies (e.g., Barnsley et al., 1992; Côté et al., 2006; Daniel \& Janssen, 1987; Grondin et al., 1984; Helsen et al., 1998; Helsen et al., 2005; Musch \& Hay, 1999; Sherar, Baxter-Jones, Faulkner \& Russel1, 2007) the size of the male soccer players subset seems to be sufficient to observe a RAE. Using Belgium's birthdates distribution and postulating that similar birth-date distributions are apparent across European countries, Helsen et al. (2005) showed a significant RAE at the under- 15 and under-17 age categories of French national youth selections. Disregarding the fact that the assertion of similar birth-date distribution across European countries is based on old references (i.e., Cowgill, 1966; Johnson, Ann \& Palan, 1975; Rosenberg, 1966), it is thus surprising not to find significant RAE in French first division. Furthermore, it should be noted that in France, soccer is the most practised organised sport (i.e., 2093456 male licensed players in 2006) and consequently that the competition to gain a place in elite teams is very high. Finally, the exportation of French elite soccer players 
1 cannot account for the absence of this effect in French first division. Nevertheless, our results

2 take the opposite view, questioning the idea of a universal RAE in this sport at the

3 professional level (Musch \& Grondin, 2001).

However, these results strengthen Bäulmer's conclusions (quoted by Musch \&

5 Grondin, 2001) that RAE gradually decreased as age increases because the physical maturity

6 advantage of children born in the first quarter over those born in the fourth wears off with

7 time, whereas technical attributes become more determinant. Thus, the competition format could represent an explanation to the absence of RAE in French male professional soccer. Professional North-American sports work in a closed system based on franchises, whereas European championships are more open because they are based on a promotion/relegation system. The purpose is to maximize profits in a closed system, whereas victories are the priority in an open system (Andreff \& Staudohar, 2000; Ferguson, Stewart, Jones \& Le Dressay, 1991; Gouguet, 2004; Jones, 1969; Neal, 1964; Noll, 2002). Profits' maximization leads to a selection of players mainly based on the immediate return they will provide to the team, which may partly depend on their physical attributes in soccer. This necessity of 16 immediate return can explain the strong over-representation in elite youth selections of players born in the first quarter given their physical maturity advantage. of RAE in the French male professional soccer championship could be the strong interventionism of the professional league. This governing body lays down strict rules about

21 financial management of elite clubs. The professional league could easily deny a promotion at the highest level to a team which does not respect certain restricting specifications. Thus, to ensure their presence in elite, French soccer clubs could choose to recruit established players with strong technical attributes, instead of a potential promising young player with strong physical attributes (Faure \& Suaud, 1999). Consequently, this 'uncompleted 
1 professionalization' (Faure \& Suaud, 1994) could explain the absence of RAE in the French

2 elite soccer championship contrary to other European countries (Musch \& Grondin, 2001;

3 Verhulst, 1992). Nevertheless, further longitudinal and cross-cultural research is needed

4 before generalizing about the 'universality' of RAE in high-level soccer.

Concerning ice hockey, our findings were consistent with past literature. To date, all

6 the studies conducted at the professional level concerned the National Hockey League. Daniel

7 and Janssen (1987) found that a RAE appeared in ice hockey at the beginning of the eighties,

8 and subsequent research consistently showed a significant RAE in NHL (Barnsley et al.,

9 1985; Grondin et al., 1984). These studies concerned only NHL and thus lacked

10 generalizability, which does not allow for a comparison with other championships. In France,

11 with very few players (i.e., 15660 male licensed players in 2006), ice hockey is a relatively

12 confidential sport. Consequently, we can reasonably assume that there is a low competition to

13 obtain a place in elite team. As seen previously, competition has been outlined as a main

14 factor generating a RAE in a given sport (Musch \& Grondin, 2001). However, our results

15 show a strong RAE in this activity. This result suggests that certain physical attributes, like

16 size or weigh, may be a necessary element not only to success in this sport and being selected,

17 but even to a continued practice.

In the conclusion of their review of the literature, Musch and Grondin (2001),

recommended a search for sports where the RAE is not observed in elite adult players. For

them, 'determining the attributes needed for success at the highest level and examining the

21 philosophy, organization, and structure of these sports' developmental programs would help

22 to identify hitherto unknown limiting factors to the effect' (p. 162). Male basketball seems to

23 be a good candidate for a closer examination. As in the current study, neither Daniel and

24 Janssen (1987) nor Côté et al. (2006) found significant RAE in this sport. This absence may 
1 be due to the fact that basketball is a sport with specific positions which allow players with

2 less physical attributes to express themselves through other abilities.

RAE and female elite sport.

Given the scarcity of past research on the RAE phenomenon among female athletes,

6 French female high-level championships were also investigated. In line with previous studies

7 (Baxter-Jones, 1995; Vincent \& Glamser, 2006), no significant RAEs were found in soccer, 8 basketball, or handball.

Looking at the French context, female athletes seem to be less likely to show RAE compared to males. The low or moderate competition for a place in elite team for all the three sports studied (i.e., respectively 50 232, 178796 and 129424 licensed female players in soccer, basketball and handball) might explain this difference. Nevertheless, it should be noted that soccer and handball are high contact sports where physical attributes are strong determinants of success and thus significant RAEs could be observed in these two activities. However, Shakib (2003) explained that the primacy of physical appearance in peer relationships during adolescence was a cause for dropout from basketball among girls. Indeed, before and after puberty, girls' peer statuses and gender statuses are conflated, creating a tension between popularity and athleticism. Thus, early maturing females are more subject to leave competitive sports than later maturing females. The potential opposite effects of an early development - athletic advantage versus gender identity conflict - may explain the 21 absence of RAE in French female elite contact sports.

\section{Conclusion}

The aim of the current investigation was to examine the presence of a RAE in French professional championships among males and females. Data analyses revealed a statistically 
1 significant RAE only among male ice hockey although it is a confidential practice in France.

2 Moreover, strong trends were detected for male handball and male rugby union. The French

3 male elite soccer case remains intriguing and further research on its background is

4 recommended. Its 'uncompleted professionalization' (Faure \& Suaud, 1994) could explain the

5 absence of RAE. Concerning females, the current investigation is in line with past studies,

6 and female athletes seem not to suffer from this effect (Baxter-Jones, 1995; Vincent \&

7 Glamser, 2006).

Our results confirm the interest of considering the prevalence of physical attributes for

9 success in one given sport and the competition for a place prior to formulate hypotheses

10 relative to a potential RAE. Nevertheless, those two indicators seem insufficient because

11 some exceptions remain in the French elite sport (i.e., male soccer and male ice hockey),

12 which suggests that other factors are prevalent to enhance or inhibit the potential RAE.

Most authors consider the RAE to be a widely held phenomenon, universal in the case

14 of professional soccer. The present findings question this universal character. The vast

15 majority of the studies conducted, including this one, were synchronic in nature, which limits

16 the possibility to conclude firmly about the RAE. Certain contradictory results speak for the

17 need of further longitudinal and cross-cultural studies. One should equally investigate various sports and/or same sports in different countries, in order to clarify the prevalence of physical attributes and internal competition. 


\section{$1 \quad$ References}

2 Andreff, W., \& Staudohar, P. (2000). The Evolving European Model of Professional Sport Finance. Journal of Sports Economics, 1, 257-276.

Barnsley, R. H., \& Thompson, A. H.. (1988). Birthdate and success in minor hockey: The key to the NHL. Canadian Journal of Behavioural Science, 20, 167-176.

Barnsley, R. H., Thompson, A. H., \& Barnsley, P. E. (1985). Hockey success and birthdate: The RAE. Canadian Association for Health, Physical Education, and Recreation, 51, $23-28$

Barnsley, R. H., Thompson, A. H., \& Legault, P. (1992). Family planning: football style. The RAE in football. International Review for the Sociology of Sport, 27, 77-88.

Baxter-Jones, A. (1995). Growth and development of young athletes. Should competition levels be age related? Sports Medicine, 20, 59-64.

Bourdieu, P., Dauncey, H., \& Hare, G. (1998). The State, Economics and Sport. Sport in Society, 1, 15-21.

Brewer, J., Balsom, P., Davis, J., \& Ekblom, B. (1992). The influence of birth date and physical development on the selection of a male junior international soccer squad. Journal of Sports Sciences, 10, 561-562.

Brewer, J., Balsom, P., \& Davis, J. (1995). Seasonal birth distribution amongst European soccer players. Sport Exercise and Injury, 1, 154-157.

Côté, J., Macdonald, D. J., Baker, J., \& Abernethy, B. (2006). When "where" is more important than "when": Birthplace and birthdate effects on achievement of sporting expertise. Journal of Sports Sciences, 24, 1065-1073.

Cowgill, U. (1966). Season of birth in man. Contemporary situation with special reference to Europe and Southern Hemisphere. Ecology, 47, 614-623.

Daniel, T. E., \& Janssen, C. T. L. (1987). More on the relative age effect. Canadian 
2 Dauncey, H., \& Hare, G. (1999). France and the 1998 World Cup: The national impact of a world sporting event. London: Franck Class Publishers.

Dine, P. (2003). The end of an idyll? Sport and society in France, 1998-2002. Modern \& Contemporary France, 11, 33-43.

Edgar, S., \& O'Donoghue, P. (2005). Season of birth distribution of elite tennis players. Journal of Sports Sciences, 23, 1013-1020.

Faure, J. M., \& Suaud, C. (1994). Un professionnalisme inachevé. Deux états du champ du football professionnel en France. Actes de la recherche en sciences sociales, 103, 726.

Faure, J. M., \& Suaud, C. (1999). Le football professionnel à la française. Paris : Presses Universitaires de France.

Feltz, D. L., \& Petlichkoff, L. (1983). Perceived competence among interscholastic sport participants and dropouts. Canadian Journal of Applied Sports Sciences, 8, 231-235.

Ferguson, D. G., Stewart, K. G., Jones, J. C. H., \& Le Dressay, A. (1991). The Pricing of Sports Events: Do Teams Maximize Profit? The Journal of Industrial Economics, 39,

Garganta, J., Maia, J., Silva, R., \& Natal, A. (1993). A comparative study of explosive leg strength in elite and non-elite young soccer players. In Reilly, T., Clarys, J., \& Stibbe, A. (Eds.), Science and Football. London: Spon.

Gouguet, J. J. (2004). Le sport professionnel après l'arrêt Bosman : une analyse économique internationale. Limoges : Presses Universitaires de Limoges.

Gouguet, J. J., \& Primault, D. (2006). The French Exception. Journal of Sports Economics, 7 , 47-59. 
hockey et au volleyball. La Revue Québécoise de l'Activité Physique, 2, 97-103.

Grondin, S., \& Trudeau, F. (1991). Date de naissance et ligue nationale de hockey: Analyses en fonction de différents paramètres. STAPS. Revue des Sciences et Techniques des Activités Physiques et Sportives, 26, 37-45.

Helsen, W. F., Starkes, J. L., \& van Winckel, J. (1998). The Influence of Relative Age on Success and Dropout in Male Soccer Players. American Journal of Human Biology, 10, 791-798.

Helsen, W. F., Starkes, J. L., \& van Winckel, J. (2000). Effect of a Change in Selection Year on Success in Male Soccer Players. American Journal of Human Biology, 12, 729-735.

Helsen, W. F., van Winckel, J., \& Williams, A. M. (2005). The relative age effect in youth soccer in Europe. Journal of Sports Sciences, 23, 629-636.

Holt, R. (1981). Sport and Society in Modern France. London: Macmillan.

Hurley, W., Lior, D., \& Tracze, S. (2001). A Proposal to Reduce the Age Discrimination in Canadian Minor Hockey. Canadian Public Policy, 27, 65-75.

Johnson, J., Ann, T., \& Palan, V. (1975). Seasonality of births for West Malaysia's two main racial groups. American Journal of Human Biology, 47, 295-307.

Jones, J. C. H. (1969). The economics of the National Hockey League. Canadian Journal of Economics, 2, 1-20.

Krouse, W. (1995). The relative age effect and elite status in the national hockey league. Unpublished manuscript. Ontario, Canada: Wilfried Laurier University.

Malina, R. M. (1994). Physical growth and biological maturation of young athletes. Exercise and Sport Sciences Reviews, 22, 389-434.

Malina, R. M., Bouchard, C., \& Bar-Or, O. (2004). Growth, maturation, and physical activity. Champaign: Human Kinetics.

Musch, J., \& Grondin, S. (2001). Unequal Competition as an Impediment to Personal 
Development: A Review of the Relative Age Effect in Sport. Developmental Review, $21,147-167$.

Musch, J., \& Hay, R. (1999). The relative age effect in soccer: Cross-cultural evidence for a systematic discrimination against children born late in the competition year. Sociology of Sport Journal, 16, 54-64.

Neal, W. C. (1964). The Peculiar Economics of Professional Sports. Quarterly Journal of Economics, 78, 1-14.

Noll, R. G. (2002). The Economics of Promotion and Relegation in Sports League. The Case of English Football. Journal of Sports Economics, 3, 169-203.

Rosenberg, H. (1966). Seasonal variations of births. National Center for Health Statistics, Vital and Health Statistics, Series 21, No. 9. Washington, DC: US Government Printing Office.

Ryan, P. (1989). The relative age effect in minor sport participation. Unpublished master's thesis. Montreal, Quebec: McGill University.

Shakib, S. (2003). Female Basketball Participation. Negotiating the Conflation of Peer Status and Gender Status from Childhood through Puberty. American Behavioral Scientist, $46,1405-1422$.

Sherar, L. B., Baxter-Jones, A. D. G., Faulkner, R. A., \& Russell, K. W. (2007). Do physical maturity and birth date predict talent in male youth ice hockey players? Journal of Sports Sciences, 25, 879-886.

Simmons, C., \& Paull, G. C. (2001). Season-of-birth bias in association football. Journal of Sports Sciences, 19, 677-686.

Stanaway, K. B., \& Hines, T. (1995). Lack of a season of birth effect among American Athletes. Perceptual and Motor Skills, 81, 952-954.

Vaeyens, R., Philippaerts, R. M., \& Malina R. M. (2005). The relative age effect in soccer: A 

match-related perspective. Journal of Sports Sciences, 23, 747-756.

2 Van Rossum, J. H. A. (2006). Relative age effect revisited: Findings from the dance domain. 3 Perceptual and Motor Skills, 102, 302-308.

4 Verhulst, J. (1992). Seasonal birth distribution of West European soccer players: A possible 5 explanation. Medical Hypotheses, 38, 346-348.

6 Vincent, J., \& Glamser, F. D. (2006). Gender differences in the relative age effect among US 7 Olympic Development Program youth soccer players. Journal of Sports Sciences, 24, 8 405-413. 
Author Note

2 Nicolas Delorme, Julie Boiché and Michel Raspaud, Laboratory Sport and social

3 Environment, University Joseph Fourier - Grenoble I.

4 Correspondence concerning this article should be addressed to Nicolas Delorme, Laboratoire

5 Sport et Environnement Social, Université J. Fourier - Grenoble I, UFRAPS, BP 53, 38041

6 Grenoble cedex 9, France. E-mail: nicolas.delorme@ujf-grenoble.fr

7

8

9

10

11

12

13

14

15

16

17

18

19

20

21

22

23

24

25 


\section{Footnotes}

${ }^{1}$ The main arguments in favour of a determinant role of the cut-off date in the RAE phenomenon where brought by Musch and Hay (1999) who showed (a) similar patterns of birthdates distribution in Germany and Brazil, in two soccer championships which share a similar cut-off date despite different climates and socio-cultural contexts, (b) an overrepresentation of players born in April, May and June in the Japanese first division soccer championship, which has April 1st as cut-off date, and (c) a shift in the birthdates distribution of professional players ten years after a change in the cut-off date was operated in the Australian youth soccer system (i.e., January 1 st was replaced by August 1st).

${ }^{2}$ Musch and Grondin (2001) also point psychological characteristics and experience as potential factors of the RAE, arguing that older children, in addition of physical advantages, are more experienced, which would lead them to experience higher levels of selfesteem, a variable that has been observed as critical for maintained sport participation (e.g., Feltz \& Petlichkoff, 1983). These issues were not developed here, since (a) they are far less supported by empirical data, contrary to the other factors and (b) the examination of their potential impact on RAE is beyond the scope of the present study. 
1 Table 1. Hypotheses concerning the prevalence of the RAE in French professional championships.

\begin{tabular}{|c|c|c|c|c|c|c|}
\hline & Ice hockey & Rugby & Handball & Soccer & Basketball & Volleyball \\
\hline Contact & Very high & Very high & High & High & Low & Absent \\
\hline \multicolumn{7}{|l|}{ Males } \\
\hline Competition & Low & Very high & Very high & Very high & Very high & Low \\
\hline $\begin{array}{l}\text { Previous } \\
\text { results }\end{array}$ & Strong RAE & $\begin{array}{c}\text { No previous } \\
\text { study }\end{array}$ & $\begin{array}{c}\text { No previous } \\
\text { study }\end{array}$ & $\begin{array}{l}\text { Strong } \\
\text { RAE }\end{array}$ & No RAE & Low RAE \\
\hline Hypotheses & High RAE & $\begin{array}{c}\text { Significant } \\
\text { RAE }\end{array}$ & $\begin{array}{c}\text { Significant } \\
\text { RAE }\end{array}$ & $\begin{array}{c}\text { Strong } \\
\text { RAE }\end{array}$ & No RAE & No RAE \\
\hline \multicolumn{7}{|l|}{ Females } \\
\hline Competition & Low & Low & Moderate & Low & Moderate & Low \\
\hline $\begin{array}{l}\text { Previous } \\
\text { results }\end{array}$ & $\begin{array}{c}\text { No previous } \\
\text { study }\end{array}$ & $\begin{array}{c}\text { No previous } \\
\text { study }\end{array}$ & $\begin{array}{c}\text { No previous } \\
\text { study }\end{array}$ & Low RAE & $\begin{array}{c}\text { No previous } \\
\text { study }\end{array}$ & $\begin{array}{c}\text { No previous } \\
\text { study }\end{array}$ \\
\hline Hypotheses & No RAE & No RAE & $\begin{array}{c}\text { Moderate } \\
\text { RAE }\end{array}$ & No RAE & No RAE & No RAE \\
\hline
\end{tabular}

2

3

4

5

6

7

8

9 
1 Table 2. Distribution of French elite athletes for 2005-2006 season.

\begin{tabular}{lccc}
\hline & Male & Female & Total \\
\hline Soccer & $329(20$ teams $)$ & $242(12$ teams $)$ & 571 \\
Basketball & $121(18$ teams $)$ & $92(14$ teams $)$ & 213 \\
Handball & $208(14$ teams $)$ & $154(12$ teams $)$ & 362 \\
Volleyball & $103(14$ teams $)$ & - & 103 \\
Rugby union & $346(14$ teams $)$ & - & 346 \\
Ice hockey & $248(14$ teams $)$ & - & 248 \\
Total & $1355(94$ teams $)$ & $488(38$ teams $)$ & 1843 \\
\hline
\end{tabular}

2

3

4

5

6

7

8

9

10

11

12

13

14

15

16

17

18

19

20

21 
1 Table 3. Season of birth of elite senior players of different genders and sports.

$\begin{array}{ccccccc}\mathbf{Q 1}(\%) & \mathbf{Q} 2(\%) & \mathbf{Q 3}(\%) & \mathbf{Q} 4(\%) & \text { Total } & \chi^{2} & p \\ \text { (expected) } & \begin{array}{c}\text { (expected) } \\ \text { (expected) }\end{array} & \begin{array}{c}\text { (expected) } \\ \text { (expection }\end{array} & & \end{array}$

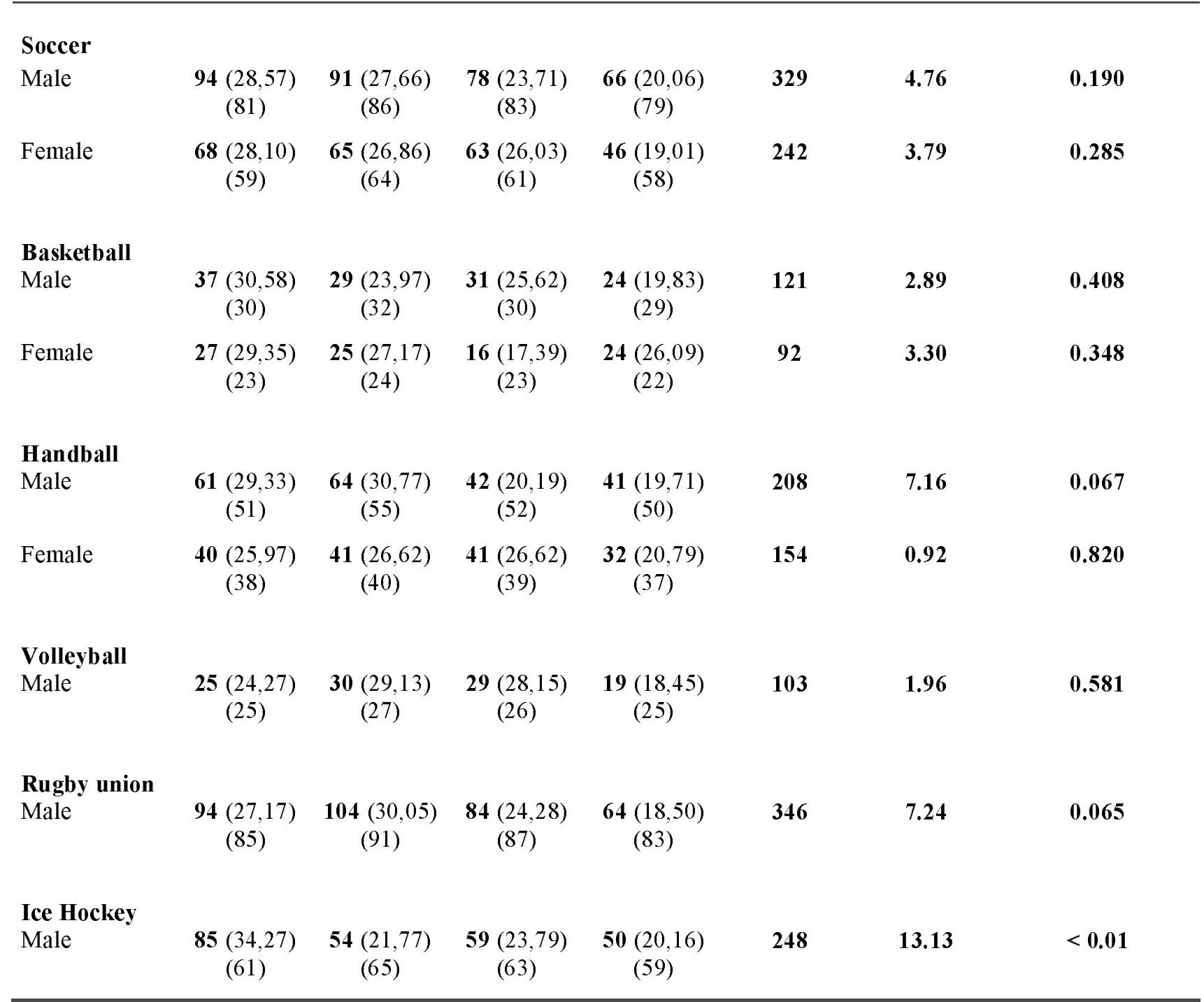

$$
\begin{aligned}
& 2 \\
& 3
\end{aligned}
$$$$
4
$$$$
5
$$$$
6
$$$$
7
$$$$
8
$$$$
9
$$ 
1 Table 4. Season of birth of French professionnal soccer players from different regions.

\begin{tabular}{|c|c|c|c|c|c|c|c|}
\hline & $\begin{array}{c}\text { Q1 (\%) } \\
\text { (expected) }\end{array}$ & $\begin{array}{c}\text { Q2 (\%) } \\
\text { (expected) }\end{array}$ & $\begin{array}{c}\text { Q3 }(\%) \\
\text { (expected) }\end{array}$ & $\begin{array}{c}\text { Q4 (\%) } \\
\text { (expected) }\end{array}$ & Total & $\chi^{2}$ & $p$ \\
\hline League 1 & $\begin{array}{c}94(28,57) \\
(81)\end{array}$ & $\begin{array}{c}91(27,66) \\
(86)\end{array}$ & $\begin{array}{c}78(23,71) \\
(83)\end{array}$ & $\begin{array}{c}66(20,06) \\
(79)\end{array}$ & 329 & 4.76 & 0.190 \\
\hline $\begin{array}{l}\text { Out of } \\
\text { France }\end{array}$ & $\begin{array}{c}18(27,69) \\
(16)\end{array}$ & $\begin{array}{c}14(21,54) \\
(17)\end{array}$ & $\begin{array}{c}19(29,23) \\
(16)\end{array}$ & $\begin{array}{c}14(21,54) \\
(16)\end{array}$ & 65 & 1.39 & 0.708 \\
\hline Total & $\begin{array}{c}112(28,43) \\
(97)\end{array}$ & $\begin{array}{c}105(26,65) \\
(104)\end{array}$ & $\begin{array}{c}97(24,62) \\
(99)\end{array}$ & $\begin{array}{c}80(20,30) \\
(94)\end{array}$ & 394 & 4.65 & 0.199 \\
\hline
\end{tabular}

4

5

6

7

8

9

10

11

12

13

14

15

16

17

18

19

20

21 